Jurnal Pemikiran Sosiologi Volume 7 No. 2, Desember 2020

\title{
Kajian Awal tentang Peran Pendatang dalam Transformasi Konflik di Papua1
}

\author{
Mohamad Baihaqi²
}

\begin{abstract}
Abstraksi
Artikel ini menjelaskan studi literatur awal tentang peran migran dalam transformasi konflik di wilayah Papua (Provinsi Papua dan Papua Barat). Konflik yang terjadi di Papua akhir-akhir ini menurut studi merupakan akibat dari kompleksitas ekonomi, sejarah, sosial termasuk ingatan kolektif masyarakat Papua dan Papua Barat. Kehadiran para pendatang yang berlatar belakang berbagai agama dan suku sering dianggap turut memperparah konflik kepentingan, terutama dengan masyarakat Papua yang pro kemerdekaan. Studi literatur menunjukkan bahwa resistensi terjadi di antara orang Papua dan di dalam diri para pendatang. Namun eksplorasi literatur dalam studi ini juga menemukan adanya kecenderungan di mana pendatang baru (pendatang) mampu beradaptasi untuk bernegosiasi dengan penduduk setempat. Kajian ini disimpulkan melalui beberapa tahapan analisis berdasarkan teori transformasi konflik. Studi ini merangkum rekomendasi pelibatan para pendatang (pendatang baru) untuk peran aktif para pendatang dalam pembangunan perdamaian dan resolusi konflik di Papua.
\end{abstract}

Kata kunci: peran pendatang, transformasi konflik, pembangunan perdamaian, resolusi konflik, Papua

\begin{abstract}
This article provides a preliminary literature study on the role of migrants in the transformation of conflicts in the Papua regions (Papua and West Papua Provinces). Recent conflicts that have taken place in Papua according to the study are the results of economic, historical, social complexities including collective memory of the people of Papua and West Papua. The presence of migrants whose background come from various religious and ethnic groups are often considered to contribute to aggravating conflicts of interest, especially with the pro independence Papuans. The literature study shows that resistance occurs among Papuans and within the migrants. However, the literature exploration of this study also find a tendency where new settlers (migrants) are able adapting to negotiate with the locals. The study is concluded through several stages of analysis based on the theory of conflict transformation. This study summarizes a recommendation for the engagement of the migrants (new settlers) for active roles of migrants in peace building and conflict resolution in Papua.
\end{abstract}

Keywords: roles of migrants (new settlers), conflict transformation, peace building, conflict resolution, Papua

\section{A. Pendahuluan}

Papua kembali bergejolak. Berangkat dari isu sektarian antara warga Surabaya dan sejumlah mahasiswa asal Papua pada 17 Agustus 2019 menyebabkan gelombang protes rakyat Papua atas pemerintahan Indonesia kembali memanas. Konflik Papua seperti bara dalam sekam yang bisa meledak kapan saja. Pemerintah Indonesia di bawah kepemimpinan Joko Widodo tampak tegang ketika kembali diuji dengan protes warga Papua hingga membakar sejumlah kantor pemerintahan dan swasta. Antara pemerintah daerah dan pemerintah pusat sempat adu argumen menanggapi gelombang protes warga Papua tersebut. Presiden Joko Widodo

\footnotetext{
${ }^{1}$ Untuk kutipan atau sitasi artikel ini: Baihaqi, Mohamad. 2020. "Kajian Awal tentang Peran Pendatang dalam Transformasi Konflik di Papua." Jurnal Pemikiran Sosiologi Vol 7 (2): 124-13

${ }^{2}$ Magister Studi Agama dan Resolusi Konflik UIN Sunan Kalijaga, Yogyakarta. Email: mohamadbaihaqi91@gmail.com
} 
menghimbau agar isu rasisme yang menjadi pemicu gelombang protes tersebut tidak dibesar-besarkan. Presiden juga meminta warga Papua bersabar dan menahan diri. Jokowi menegaskan bahwa pemerintah Indonesia akan menjaga kehormatan Papua dan Papua Barat serta berjanji meningkatkan kesejahteraan warga. Selain itu, Presiden berjanji dalam waktu dekat akan berkunjung dan mengadakan dialog bersama warga Papua dan Papua Barat (Kompas.com, 2019). Menanggapi pernyataan Presiden, Gubernur Papua, Lukas Enembe menyayangkan pernyataan Pemerintah Indonesia yang ia nilai tidak tegas dalam merespon gelombang protes warga Papua. Enembe meminta Presiden agar segera bergerak dan menyelesaikan kasus rasisme dengan menangkap para pelaku ujaran kebencian dan persekusi yang dialami oleh mahasiswa asal Papua. Tindakan rasis terhadap warga Papua di Jawa menurut Enembe telah dialami selama bertahuntahun. Itu sebabnya ia mempertimbangkan untuk memulangkan seluruh mahasiswa Papua yang tengah belajar di Jawa (https://www.papua.go.id/viewdetail-berita-6803/gubernur-pernyataan-presidentak-obati-luka-rakyat-papua.html).

Perselisihan antara Papua dan Pemerintah Indonesia memang sudah mengemuka sejak tahun 1960an. Pada waktu itu, rakyat Papua telah menuntut pemisahan diri dari Indonesia. Hal tersebut dilatarbelakangi oleh permasalahan sejarah, politik dan ekonomi (Ahmad Asi dkk, 2011: 34). Namun persoalan Papua di era itu belum dilihat secara serius. Bahkan saat Orde Baru, pemerintah Indonesia mengeluarkan kebijakan membuka tambang di Papua dan menempatkan Papua sebagai tujuan prioritas transmigrasi. Pemerintah Indonesia tampak mulai serius menangani konflik di Papua sejak pasca reformasi pada 1999 di era Presiden BJ Habibie (ibid). Pada saat itu pemerintah Indonesia menetapkan status Papua dan Papua Barat sebagai Daerah Otonomi Khusus. Kendati demikian konflik Papua tak serta merta tuntas. Papua terus begejolak dari masa ke masa. Pelbagai kebijakan telah dilakukan Pemerintah Indonesia semenjak Presiden Habibie, Abdurrahman Wahid, Megawati Soekarno Putri, Soesilo Bambang Yudhoyono hingga Joko Widodo, namun tidak sepenuhnya berhasil. Konflik di Papua dan Papua Barat semakin kompleks dan membutuhkan penyelesaian yang konrehensif, di samping memang membutuhkan pihak ketiga yang mampu bersikap netral dalam melaksanakan dialog maupun rekonsiliasi.

Konflik antara pemerintah Indonesia, Papua dan Papua Barat akan terus terjadi jika tidak diselesaikan secara dialogis. Gejolak dan imajinasi kolektif terhadap kekerasan di masa lalu akan terus tumbuh dari imajinasinya masing-masing. Terlebih diperparah dengan kesenjangan ekonomi antara Papua dan kawasan lain. Konflik akan semakin mudah tersulut ketika momen-momen kontestasi politik nasional dihelat. Disana instrumentalisasi konflik terus mengancam jika konflik potensial dibiarkan tanpa penyelesaian yang efektif. Karena itu dibutuhkan strategi dan arah pengelolaan dan penyelesaian yang konprehensif. Transformasi konflik perlu dilakukan oleh pihak-pihak ketiga yang netral. Baik lewat dialog yang menghasilkan 
Jurnal Pemikiran Sosiologi Volume 7 No.2 2020

Kajian Awal tetang Peran Pendatang dalam Transformasi Konflik di Papua

Mohamad Baihaqi

kesepakatan-kesepakatan dengan warga Papua tanpa bertumpu penuh kepada peran elit Papua yang selama ini memanfaatkan kebijakan otonomi khusus daerah Papua untuk meraup keuntungan. Konflik di Papua tidak hanya satu arah melainkan muncul dalam skala dan level konflik antar orang yakni pendatang dan masyarakat Papua (intergrouf conflict) antar kelompok Organisasi Papua Merdeka (OPM), elit dan sipil (intergroup conflict), antar kelompok dan negara yakni separis (OPM) dengan Pemerintah Indonesia (vertical conflict) (Novri Susan, 2018: 8). Keputusan untuk melibatkan militer serta pihak lain di tataran International sudah menjadi gagasan lama. Namun pembicaraan tentang pihak pendatang di Papua dan Papua Barat hanya dipandang sebagai salah satu pemicu konflik. Untuk itu perlu dilihat lebih jauh, bagaimanakah posisi pendatang di Papua dan Papua Barat? Seberapa resisten warga Papua terhadap warga pendatang? Apakah pendatang atau perwakilan bisa berperan sebagai pihak ketiga yang mampu menyatukan pemerintah Indonesia dan Papua?

Penelitian terkait konflik Papua sudah banyak dilakukan baik oleh organisasi maupun individu secara nasional maupun internasional. Dalam riset ini akan dikaji peran pendatang dalam peersoalan antara Papua dan Papua Barat dengan Pemerintah Indonesia yang tak kunjung selesai. Penelitian yang dianggap relevan dan menyingggung peran pendatang antara lain pernah dilakukan oleh Lembaga Ilmu Pengetahuan Indonesia (LIPI), Road Map Papua (2010), Pengelolaan Konflik di Indonesia-Sebuah Analisis Konflik di Maluku, Papua dan Poso (2011), dilakukan oleh Current Asia dan The Centre for
Humanitarian Dialogue. Selain itu dalam buku Nasionalisme dan Konflik Etnis di Indonesia Jaques Betrand (2012) memaparkan persoalan konflik Papua. Ave Levaan (2012) misalnya juga menulis tesis mengenai etnosentrisme dan politik representasi di era otonomi khusus di Papua. Ngadisa (2003) menulis tentang konflik pembangunan dan gerakan politik di Papua. Dari penelitian sebelumnya, pendatang acapkali dilihat secara negatif dalam artian diposisikan sebagai salah satu variabel yang menyebabkan konflik yang selama ini terjadi. Meski dalam penelitian The Centre for Humanitarian Dialogue menyinggung soal peran pendatang dalam dialog antara Pemerintah Indonesia dan Papua namun pembahasan tentang peran para pendatang tidak mendalam.

Sementara itu, Cahyo Pamungkas (2016) meneliti tentang Muslim Papua dan Muslim Pendatang yang mengalami pertarungan identitas antara keindonesiaan dan kepapuaan. Cahyo mengambil sampel Muslim pendatang di daerah Jayapura karena disanalah ormas-ormas Islam mulai berkembang. Dalam penelitian ini, Cahyo menyimpulkan terdapat pertautan antara Muslim pendatang lewat pelbagai macam ormas seperti NU, Muhammadiyah dengan integrasi nasionalisme Indonesia. Kajian Cahyo Pamungkas (2016) memandang peran penting pendatang sebagai pihak ketiga dalam upaya dialog antara Pemerintah Indonesia dan Papua. Pendekatan lewat jalur militeristik terbukti tidak berhasil menyelesaikan persoalan, malah menjadikan konflik semakin menajam. Rekomendasi penelitian Cahyo Pamungkas 
tersebut menyimbulkan bahwa pihak ketiga dituntut netral dan mampu mewakili kedua belah pihak. Karenanya peran pendatang sebetulnya bisa memenuhi prasayarat tersebut (Pamungkas, Cahyo, 2016: 249-264).

\section{B. Metode dan Kerangka Teoritik}

Kajian awal ini memfokuskan diri pada tema terkait pendatang di Papua dan Papua Barat. Metode yang digunakan dalam kajian awal ini menggunakan metode literatur kepustakaan yang bersifat kualitatif dengan penelusuran informasi dan data berdasarkan data dari buku, tesis, disertasi jurnal ilmiah, laporan media massa, serta referensi dari hasil laporan dan riset lembaga-lembaga non pemerintah seperti NGO. Referensi dari sumber lain berguna untuk membandingkan hasil penelitian dan perspektif baik dari lembaga di bawah naungan pemerintah maupun lembaga di luar pemerintah.

Kajian awal melalui studi kepustakaan ini dilakukan untuk mengetahui konteks mengenai timbulnya konflik dan kehadiran pendatang di Papua. Pandangan dari pelbagai aspek tersebut dilihat untuk mengukur sejauh mana para pendatang turut serta dalam proses dialog yang selama ini dilakukan antara Pemerintah Indonesia dan Papua. Data-data yang diperoleh dari pelbagai macam sumber kemudian dikumpulkan dan dianalisis sesuai dengan topik tematis. Setelah itu, akan dipaparkan kaitan data dengan konteks eksternal dari aspek sosial, budaya dan agama. Secara teoritis, konflik adalah ekspresi heterogenitas kepentingan nilai, dan keyakinan yang muncul sebagai formulasi baru akib at dari perubahan sosial yang muncul bertentangan dengan hambatan yang diwariskan. Pengelolaan konflik tidak bersifat statis. Penyelesainnya bersifat dinamis dan berkembang untuk mengatasi dan memahami perubahan sifat konflik. Pemikiran tentang resolusi dan transformasi konflik pun terus berubah sesuai dengan kondisi dan dengan begitu mesti menyesuaikan respon terhadap pengelolaannya (Mial,l Ramsbotham \& Woodhouse, 2002: 7-8).

Persoalan Papua merupakan konflik yang kompleks, menyangkut persoalan sejarah sejak era kolonial, ekonomi-industrialisasi, budaya yang berhubungan dengan kultur masyarakat setempat serta persoalan politik antara pemerintah Indonesia dan pemerintah daerah yang semakin karut marut dengan adanya otonomi khusus yang hingga hari ini tidak kunjung menyelesaikan permasalah. Selain itu dalam konteks sosial-masyarakat persolan adanya pendatang yang secara umum adalah orang yang datang dari tempat lain untuk menetap di suatu tempat (KBBI daring). Kajian ini memfokuskan pembahasan pada peran dan dampak pendatang. Perpindahan penduduk yang memuncak setelah kebijakan Orde Baru menjadikan Papua sebagai sasaran prioritas transmigrasi. Migrasi merupakan suatu bentuk gerak penduduk geografis, spasial atau teritorial antara unit-unit geografis yang melibatkan perubahan tempat tinggal yaitu dari tempat asal ke tempat tujuan. Migrasi dibagi menjadi dua jenis yakni migrasi internal dan migrasi internasional (Rusli, 1996: 138). 
Migrasi yang terjadi di Papua umumnya adalah migrasi internal atau yang disebut sebagai transmigrasi. Dengan kata lain transmigrasi merupakan bentuk migrasi internal yang terjadi di Inondesia. Proses transmigrasi di Indonesia dikenal sebagai transmigrasi umum yakni transmigrasi yang disponsori oleh pemerintah. Sedangkan transmigrasi non pemerintahan disebut transmigrasi swakarsa atau transmigrasi yang terjadi secara spontan (ibid: 139). Transmigrasi swakarsa atau spontan di Papua terjadi tampak massif ketika dibuka aktivitas tambang yang menuntut kompetensi sumber daya manusia dari daerah lain. Pendatang selama ini dilihat secara negatif. Dalam artian pendatang dilihat sebagai salah satu aktor yang menimbulkan kecemburuan antara warga setempat dengan pendatang serta mengakibatkan populasi masyarakat setempat menyusut, dan jumlah pendatang semakin meningkat. Pendatang dalam hal ini diletakkan sebagai pihak ketiga yang berpotensi mampu berperan penting dalam upaya dialog antara pemerintah Indonesia dan masyarakat Papua.

Proses penyelesaian konflik bergerak secara dinamis sehingga dalam tulisan ini, pendatang lebih diposisikan sebagai pihak ketiga. Dari sana proses transformasi konflik membutuhkan pihak ketiga yang menjembatani kepentingan Pemerintah Indonesia dengan aspirasi masyarakat Papua. Karena itu tranformasi konflik sangat penting dilakukan sebagai langkah penting di luar penyelesaian konflik. Transformasi konflik menjadi pengembangan dari penyelesaian konflik. Istilah ini mempunyai peran tertentu dalam sebuah konflik yang tidak simetris.
Tujuan transformasi konflik adalah mengubah hubungan sosial yang tidak adil antar masyarakat dengan masyarakat maupun masyarakat dengan pemerintah. Istilah transformasi juga digunakan untuk memahami proses perdamaian (Op.Cit: 31)

Transformasi konflik sebagai tingkat perubahan terdalam pada proses penyelesaian konflik. Dalam konteks tersebut transformasi bermakna sebuah urutan langkah-langkah transisi yang dibutuhkan dalam merespon konflik. Istilah ini juga mengimplikasikan sebuah transformasi mendalam pada pihak-pihak yang bertikai serta dalam situasi yang menciptakan konflik (Miall, Rasbotham, Woodhouse, 2002: 32). Dalam kekuasaan yang tak seimbang, konflik bergerak secara tidak simetris, Van Der Merwe seperti yang dikutip oleh Miall dkk (2002) menawarkan skema transformasi konflik sebagai berikut: (1) memahami unsur penindasan; (2) mengidentifikasi bentuk-bentuk ketidakadilan, (3) mengenali konflik laten yang dapat ditransformasi dengan menanamkan kesadaran kepada masyarakat secara hati-hati. Lewat penanaman kesadaran pihak ketiga dapat melakukan mobilisasi dan pemberdayaan masyarakat lewat pelbagai macam program. Setelah itu dibutuhkan konfrontasi konflik yang jelas. Konfrontasi konflik yang jelas dapat dilakukan dengan melihat hubungan apa yang hendak diubah, dan keseimbangan kekuasan macam apa yang dibutuhkan. Apakah menghendaki semacam kekuasan baru di daerah. Setelah menganalisis hal tersebut, pihak ketiga dapat melihat sikap apa yang perlu diubah atau ditansformasikan ditengah masyarakat. Barulah kemudian masuk ke 
tahap negosiasi dan mediasi untuk memperoleh kesepakatan bersama antar masyarakat dan seluruh perwakilan atau elit pihak-pihak yang berkonflik (ibid: 26).

\section{Deskripsi Kajian: Posisi Pendatang di Papua dan Papua Barat}

Terdapat empat faktor yang membuat situasi politik di Papua semakin suram. Pertama, tidak tuntasnya pembicaraan mengenai legitimasi politik bagi pemberlakuan otonomi khusus. Para elit Papua ada yang belum merasakan dampak berarti dari keberadaan otonomi khusus (otsus). Kedua, Rendahnya sikap saling percaya sehingga otonomi khusus hanya dinilai sebagai kebijakan sepihak yang didorong oleh kepentingan pemerintah Indonesia. Ketiga, masyarakat Papua merasa bahwa belum tampak keberhasilan otsus dalam pelbagai aspek yang menyentuh kehidupan keseharian mereka. Keempat, belum adanya rasa keadilan bagi korban kekerasan khususnya dalam penyelesaian sejarah konflik masa lalu ketika di Papua diberlakukan status Daerah Operasi Militer (DOM) dan operasi militer lainnya. (Amruddin al Rahab, 2010: 136).

Dari persoalan di atas, langkah yang paling akhir adalah dialog. Dialog diposisikan bukan sebagai strategi untuk mengakali. Melainkan sebagai pembuka jalan perdamaian tanpa kekerasan dan menebar teror. Kemampuan dan kenetralan pihak ketiga dibutuhkan bagi kedua belah pihak (ibid: 153). Sebagai penduduk yang telah beradaptasi dengan masyarakat Papua dan Papua Barat peran pendatang berpotensi sebagai pihak ketiga. Posisi pendatang selama ini dianggap sebagai salah satu sumber masalah. Sejak keputusan pemerintah orde baru yang menjadikan Papua sebagai tujuan transmigrasi, pendatang mulai meningkat. Kedatangan transmigran umum maupun spontan menurut Jaque Bertrand (2012) menyebabkan orang-orang Papua hanya mendapat sedikit keuntungan dari pembangunan ekonomi provinsi. Tambang emas di Freeport semenjak dibuka pada 1973 hanya menghasilkan keuntungan besar bagi investor asing. Selama tiga kuartal pertama pada 1980, penjualan kotor dari hasil tambang PT Freeport mencapai $\$ 122$ juta dan pemerintah Indonesia memperoleh hasil sebesar \$ 22 juta. Di balik itu orang-orang Papua tak merasa memperoleh keuntungan berarti. Sebab hanya segelintir orang yang dipekerjakan di tambang emas itu. Hal tersebut hanya untuk pekerja dengan keterampilan rendah (Jacques Betrand, 2012: 244). Selebihnya pekerjaan di sektor areal tambang dikuasi oleh pekerja dari luar atau pendatang dari daerah lain.

Migrasi bagi sebagian kalangan mengancam kehidupan orang-orang Papua dan mayoritas demografis mereka. Sebagian migrasi setelah 1969 bersifat spontan. Pemerintah Indonesia pun tidak berusaha mengurangi alirannya, malah sebaliknya. Program transmigrasi menyebabkan pendatang melonjak. Pada tahun 1977, setelah Papua ditunjuk sebagai tujuan prioritas imigrasi, diperkirakan jumlah transmigrasi mencapai 70.000 hingga 150.000 pendatang (ibid: 245). Bahkan pemerintah Indonesia saat itu menargetkan jumlah pendatang di Papua dan 
Papua Barat sebesar 1, 7 juta. Dibandingkan dengan penduduk asli Papua pada kurun 1979-1989 berjumlah sekitar 1, 2 juta jiwa (ibid). Kebijakan itu menyebabkan orang-orang Papua seakan menjadi minoritas di daerahnya sendiri. Sebagian pihak menilai kebijakan pemerintah Indonesia dapat mengancam eksistensi masyarakat asli Papua. Meski demikian, orang-orang Papua sendiri banyak yang tak merespon kebijakan tentang transmigrasi itu secara reaktif.

Formasi pupulasi di Papua pada tahun 2000 sebesar 2,6 juta, dimana 1,6 juta orang adalah orang asli Papua dan 1 juta adalah para pendatang spontan (yang melakukan migrasi lewat jalur kekerabatan dan telah lama ada di Papua) dan transmigran yang disponsori oleh pemerintah (terutama sejak masa Orde Baru). Sebagian besar gelombang masuk adalah para pendatang ke kota-kota besar daerah itu. Sehingga penduduk Jayapura meningkat dari 50.00080.000. Jumlah pendatang meningkat sedangkan penduduk setempat stabil, tanpa banyak perubahan sejak 1950. Terutama karena kesehatan masyarakat setempat memburuk dan angka kematian bayi meningkat (ibid: 246). Hal ini seakan nampak kontras karena kelompok pendatang justru memperoleh akses kepada sumber daya seperti tanah dan pekerjaan. Hal ini terjadi karena para pendatang kebanyakan mengikuti anjuran pemerintah terutama dalam mendorong penanaman padi yang berkembang dari 900 ton pada 1974 menjadi 52.000 ton pada 1990, terutama di daerah-daerah transmigrasi. Ironi di masa orde baru itu memperparah kesenjangan sosial dan budaya antara penduduk asli dan pendatang karena pemerintah tidak menggelontorkan subsidi untuk produksi makanan pokok warga asli berupa sagu. Di kawasan pesisir, warga Papua bersaing dengan nelayan dari Sulawesi Selatan dan Tenggara yang menggunakan peralatan yang lebih moderen (ibid).

Dampak lanjutan konflik di Papua semenjak masa orde baru hingga kini dapat direpresentasikan antara kelompok-kelompok pro-NKRI dan pro-Papua merdeka. Meski demikian terdapat di antara kedua kubu tersebut wilayah "abu-abu" yang dinisbatkan terhadap kelompok-kelompok NGO, organisasi keagamaan, media massa dan mahasiswa. Di ranah "abu-abu" ini kelompok-kelompok keagamaan misalnya pendatang Muslim lewat ormasnya seperti Muhammadiyah, Nahdlatul Ulama, dan Majelis Ulama Indonesia (MUI) memainkan peran negosiasi keagamaan sekaligus negoisasi kebangsaan (Cahyo Pamungkas, 2016: 250). Namun ketika elit-elit ormas tersebut yang sebagian merupakan pendatang, mencalonkan diri sebagai elit dalam pemerintahan termasuk melalui parpol, telah turut menyebabkan kecemburuan di kalangan beberapa elit yang berasal dari masyarakat adat Papua sendiri (ibid: 253). Hal itu menunjukkan bahwa sentimen rasial yang sesungguhnya masih bersifat laten sesuangguhnya masih dapat dirasakan pengaruhnya dalam watak elitelit politik di Papua (baik dari kalangan pendatang maupun di kalangan masyarakat adat). Terlebih perebutan kekuasaan politik di tingkat elit lokal semakin kuat pasca pemekaran Provinsi Papua Barat pada 2003. Padahal kenyataannya, banyak penelitian yang telah menunjukkan bahwa di akar rumput, 
pembauran dan penerimaan masyarakat asli Papua justru terbuka dan cair dalam berinteraksi dengan sejumlah pendatang.

Di kota Manokwari misalnya, bupati dari suku Arfak menghimbau agar masyarakat memilih bupati dari warga asli Arfak. Semenjak adanya otonomi khusus, sentimen kesukuan antar elit-elit baru di Papua Barat malah semakin menajam. Di kota Manokwari, sektor-sektor ekonomi informal dikuasai oleh pendatang yang antara lain berasal dari Sulawesi, Jawa, Maluku dan sebagian daerah lain. Sedangkan pendatang transmigrasi tersebar di daerah-daerah pinggiran kota Manokwari seperti Prafi, Waseki, dan Ransiki. Selain pertanian, perkebunan dan kelapa sawit juga dilirik oleh pendatang (I Ngurah Suryawan, 2013: 293). Para pendatang juga membuka usaha dengan membuat toko-toko kelontong. Sedangkan tanah-tanah adat dibangun oleh kalangan elit di Papua Barat sebagai kantor-kantor pemerintahan. Di tengah himpitan pergeseran sosial akibat munculnya elit-elit baru di Papua Barat baik pendatang maupun warga asli menyebabkan sentimen identitas dan perebutan kekuasan lokal terus terjadi antara pendatang, elit, dan warga asli Papua (ibid).

Memori kolektif masyarakat Papua salah satunya dianggap menjadi pemicu resistensi bagi generasi muda Papua untuk melakukan perlawan. Akumulasi kekerasan yang dilakukan oleh pemerintah Indonesia khususnya di era orde baru bertransformasi menjadi energi kolektif yang mendorong semangat perlawanan terhadap khususnya pemerintah pusat Indonesia. Muara dari hal tersebut dapat dilihat dari perlawananperlawanan simbolik misalnya dengan mengibarkan bendera Bintang Kejora (Amiruddin al Rahab, 2010: 178). Akumulasi kebencian tersebut juga berdampak pada sentimen masyarakat Papua terhadap kedatangan para pendatang baru dari pelbagai daerah di Indonesia.

\section{Peran Pendatang dalam Transformasi Konflik di Papua dan Papua Barat}

Saat ini posisi pendatang berdasarkan perkembangan konflik mutakhir di Papua pada 2019 lalu menunjukkan posisi pendatang masih resisten. Itu bisa dilihat dari penembakan para pendatang di Wamena. Diketahui, kerusuhan yang terjadi di Kota Wamena, Kabupaten Jayawijaya, Papua tersebut mengakibatkan puluhan orang meninggal dunia dan 70 orang luka-luka. Kantor bupati dan kantor pemerintahan lainnya dibakar, pusat perekonomian dan rumah warga dirusak. Diduga pelaku pembunuhan dilakukan oleh sekelompok pemberontak. Meski tujuh oknum pelaku berhasil ditangkap

(https://regional.kompas.com/read/2019/09/26/05 330041/7-fakta-baru-kerusuhan-wamena-30-orangtewas-hingga-dalang-kerusuhan?page=all). Dibalik itu, warga asli Papua ikut membantu para pendatang untuk menyelamatkan dirinya dari serangan beberapa pelaku kerusuhan. Warga asli Papua mengevakuasi para pendatang ke gereja setempat (https://regional.kompas.com/read/2019/10/01/06 360081/cerita-warga-pendatang-diselamatkanorang-asli-papua-saat-kerusuhan-wamena?page=all). 
Hal tersebut menunjukkan bahwa warga asli Papua sebetulnya bersifat akomodatif dan memiliki sensibilitas kemanusiaan terhadap keberadaan para pendatang yang dilihat oleh sejumlah peneliti sebelumnya sebagai salah satu sumber masalah. Artinya bahwa para pendatang secara sosial juga telah berusaha untuk berhasil membaur dan relatif diterima oleh masyarakat di Wamena, Papua.

Secara sosial, masyarakat sudah berbaur antara penduduk asli maupun pendatang. Ismail Suardi Wekke (2013) dalam penelitiannya melihat bahwa suku Kokada di Papua Barat terutama anggota suku yang tinggal di Kota sudah berbaur dengan pendatang maupun suku lain. Di tempat tersebut, masyarakat mengangkat kepala suku secara langsung. Melalui kepala suku inilah aspirasi masyarakat ditampung. Setiap keperluan dan perselisihan antar warga akan ditangani kepala suku. Keragaman budaya dan agama di tempat tersebut tidak lagi menjadi persoalan (Suardi Wekke, 2013: 124).

Peran pendatang di Papua dan Papua Barat juga diperkuat dengan faktor bertahannya para pendatang karena faktor-faktor yang berhubungan dengan pribadi dan kemampuan menghadapi pelbagai rintangan. Said Rusli mengutip Lee yang membagi faktor-faktor yang menyebabkan pendatang bisa bertahan atau tidak di daerah lain ke dalam tiga jenis. Pertama, faktor yang bertindak untuk mengikat orang dalam suatu daerah atau mengikat orang terhadap daerah itu yang disebut sebagai faktor minus. Kedua faktor yang cenderung menolak para pendatang yang merupakan faktor plus. Ketiga, faktor indifferen yakni tak punya pengaruh untuk menolak dan mengikat (Said Rusli, 1996: 144). Faktor plus dan minus dapat disejajarkan dengan kekuatan sentripetal dan sentrifugal atau faktor internal dan eksternal yang mempengaruhi individu-individu para pendatang. Apakah akan menetap di daerah baru atau meninggalkan daerah yang bersangkutan.

Kekuatan internal sangat berpengaruh untuk memengaruhi para pendatang untuk tetap tinggal. Sedangkan faktor eksternal mendorong pendatang untuk meninggalkan daerah tersebut. Faktor internal dipengaruhi oleh misalnya jarak dan biaya transfortasi antar daerah (ibid: 145). Sedangkan faktor eksternal berhubungan dengan taraf lingkaran hidup di daerah yang didatangi. Faktor adaftif individu terhadap perubahan lingkungan baru juga berpengaruh.

Sejak mulainya program transmigrasi tidak sedikit para pendatang dapat bertahan di Papua dan Papua Barat. Itu artinya para pendatang berhasil bertahan dari rintangan-rintangan dan mampu beradaptasi dengan lingkungan baru atau masyarakat setempat. Disamping itu hal tersebut menunjukkan bahwa masyarakat Papua dan Papua Barat sebetulnya dapat menerima para pendatang dengan baik. Mengutip Petersen, Sunarto (1985) menjelaskan bahwa migrasi internal di Indonesia masih termasuk ke dalam tipe primitif yang lebih menekankan pada hubungan antar manusia dengan alamnya daripada dengan normanya. Ia juga melihat terdapat dua kecendurngan para pendatang sehingga memutuskan untuk melakukan transmigrasi yaitu: apabila seorang 
pergi ke daerah lain dengan maksud mendapatkan sesuatu yang baru maka maka pendatang tersebut disebut sebagai pendatang Inovatif. Sedangkan orang yang datang ke daerah lain karena respon terhadap perubahan lingkungan-sosial atau akibat bencana alam disebut sebagai pendatang konservatif (Sunarto, 1985: 90-100). Dengan kata lain, perpindahan penduduk dari desa ke kota disebut sebagai pendatang inovatif, sedangkan penduduk yang datang dari kota ke desa disebut sebagai pendatang konservatif. Sehingga menurut Sunarto, pendatang yang disebabkan karena proses transmigrasi, masuk dalam kategori penduduk konservatif (ibid). Itu sebabnya pendatang di Papua dapat dibagi menjadi dua, yakni pendatang yang disebabkan karena kebijakan transmigrasi disebut sebagai pendatang konservatif, sedangkan pendatang yang disebabkan karena adanya aktivitas tambang disebut sebagai pendatang inovatif.

Resistensi masyarakat Papua selama ini tampak dari para pentadang inovatif karena para pendatang inovatif dianggap sebagai sumber kecemburuan sosial di tengah kehidupan sosialekonomi masyarakat Papua. Pendatang inovatif dianggap sebagai ancaman yang bisa mengambil alih keuntungan dari aktivitas tambang dan industrisasi lainnya. Sedangkan pendatang konservatif yang merupakan akibat dari kebijakan tranmigrasi relatif lebih diterima dan membaur dengan masyarakat, khususnya masyarakat Papua yang pro terhadap NKRI. Posisi pendatang konservatif yang relatif telah membaur secara sosial-kultural dengan masyarakat Papua dapat dijadikan ssebagai komunikator utama dalam proses dialog antara Pemerintah Indonesia dengan Pemerintah Papua. Peran pendatang saat ini dituntut aktif dan lebih mampu berinteraksi secara positif dalam proses transformasi konflik di Papua dan Papua Barat. Seberapa efektif peran perwakilan para pendatang terlibat sebagai pihak ketiga dalam konflik laten antara Pemerintah Indonesia dengan Papua dan Papua Barat?

Setelah otonomi khusus, Majelis Rakyat Papua, dan dialog antar elit lainnya tidak mampu meredam konflik potensial di Papua, maka dibutuhkan skema baru dan pihak ketiga yang memiliki komitmen kebangsaan sekaligus dapat membaur dengan masyarakat Papua lainnya. Meski di akar rumput masyarakat Papua terpecah menjadi dua yakni masyarakat Papua pro NKRI dan pro kemerdekaan Papua. Pihak ketiga dalam hal ini pendatang yang telah lama tinggal di Papua, dapat melakukan pendekatan secara kultural terutama terhadap masyarakat Papua yang pro kemerdekaan. Terutama pihak pendatang yang menetap cukup lama di Papua dan Papua Barat.

Para pendatang berinteraksi dan membaur secara sosial dengan pihak setempat. Dari itu dibutuhkan strategi untuk mengubah struktur konflik dan sebuah pola komunikasi yang berbeda sehingga memungkinkan pihak ketiga menyaring atau melihat kembali pesan-pesan, sikap, perilaku pihak yang berkonflik. Intervensi pihak ketiga dibutuhkan dengan tujuan dapat mengurangi spiral umpan balik antar pihak yang bersengketa (Miall, Ramsbotham \& Woodhouse, 2002: 15). Pihak ketiga sebetulnya dapat 
mengubah tidak hanya struktur komunikasi melainkan juga dapat menciptakan keseimbangan. Langkah semacam itu dilakukan misalnya dengan mengadakan negoisasi, fasilitasi dan mediasi antar elit-elit dalam pemerintah Indonesia maupun elit masyarakat Papua, baik dalam kondisi terpaksa maupun lewat kesadaran penuh. Namun langkah tersebut berbahaya jika pihak ketiga berasal dari penguasa yang dapat menyeretnya ke dalam konflik yang terlibat penuh. Dalam artian, ketika pemerintah Indonesia memberikan dorongan bagi penyelesaian konflik pada saat yang sama terjadi ambiguitas. Lewat kekuasaan yang dimiliki Pemerintah Indonesia dapat menertibkan, memaksa dan memerintah pihak lain. Itu sebabnya Pemerintah mesti dapat membedakan antara mediator yang berkuasa dengan mediator yang tidak memiliki kekuasaan. Perannya dapat ditentukan hanya untuk kepentingan komunikasi dan fasilitasi (ibid: 16-17).

$$
\text { Mengharapkan kehadiran pemerintah }
$$
Indonesia sebagai pihak ketiga sudah dilakukan sejak era Presiden BJ Habibie, namun langkah tersebut tidak berhasil karena melihat konflik di Papua bergerak secara simetris. Perlu dilihat konflik macam apa yang terjadi di Papua. Apakah konflik tersebut bergerak antar pihak yang relatif sama (simetris) atau berhadapan dengan konflik yang yang lebih komplek (tidak simetris). Konflik Papua dan Papua Barat diposisikan sebagai konflik jenis kedua. Selama ini lemahnya kapasitas institusional masyarakat membuat perluasan konflik seringkali terjadi. Kelemahan ini ditandai dengan kegagapan gerakan sosial dan organisasi sipil menyemai tradisi dan mendorong aksi kewarganegaraan yang terbuka menggunakan instrumen demokrasi (Amien Tohari dkk, 2011: 229). Dalam konteks ini, para pendatang di Papua dapat melakukan hal ini lewat pelbagai strategi komunikasi di tengah masyarakat. Struktur komunikasi antara Pemerintah Indonesia terhadap Masyarakat Papua dapat melalui pihak pendatang. Pihak ini dapat bekerja mentransformasikan konflik potensial yang dipendam oleh masyarakat Papua secara hati-hati lewat pergaulan sosial dan kultural sehari-hari. Proses semacam ini adalah upaya menanamkan kesadaran kepada masyarakat secara hati-hati lewat transformasi konflik dengan tahapan sebagai berikut.

Pertama, lewat penanaman kesadaran. Dalam konteks ini, pendatang dapat melakukan mobilisasi dan pemberdayaan masyarakat lewat pelbagai macam program yang didukung oleh pemerintah Indonesia. Proses mengimplementasikan program pemerintah Indonesia lewat pendatang bertujuan untuk mengalihkan energi negatif masyarakat Papua yang dilatarbelakangi memori kolektif kekerasan Pemerintah Indonesia di masa lalu menjadi energi positif yang bersifat lebih konstruktif. Karenanya, pihak pendatang sebagai pihak ketiga dapat memulai perannya lewat persoalan-persoalan sederhana di distrik masing-masing. Hal ini akan menciptakan efek komulatif yang dapat memupuk kerja sama antar pihak yang memendam konflik potensial yakni antara masyarakat Papua Pro NKRI dan Pro Kemerdekaan. Di samping dapat mencari bentuk transformasi alternatif mencapai kesepakatan bersama. Meski di satu sisi berpotensi timbulnya sikap tidak percaya satu sama 
lain dan tidak bersedia bekerjasama. Pihak ketiga kemudian dapat mecari usulan dari masing-masing pihak (Pec Pickering, 2001: 1006-107). Sehingga pihak ketiga mampu mendinginkan emosi masingmasing. Salah satu teknik transformasi konflik yakni lewat pola contentious, pendatang selaku pihak ketiga mampu membuat masyarakat Papua kurang menyadari bahwa dirinya merupakan bagian dari usaha untuk menanamkan kesadaran terhadap perdamaian. Bahkan, efektivitasnya terukur dari misalnya apakah terjadi semacam resistensi yang bersumber dari penolakan masyarakat Papua. Apabila pihak lain mampu membaca atau melihat apa yang sesungguhnya tujuan dari pihak ketiga maka pola semacam ini tidak sepenuhnya bisa berjalan efektif. Karena itu, para pendatang sebagai pihak ketiga pun mesti berhati-hati. (Pruitt \& Rubin, 2009: 102).

Dalam konflik tidak simetris pemerintah Indonesia akan selalu menang. Sedangkan Papua sebagai pihak yang selama ini dianggap lemah selalu kalah oleh kekuatan yang lebih besar. Satu-satunya cara untuk mentranfromasikannya adalah dengan transformasi struktur terbawah secara sosial dan kultural dalam memori kolektif masyarakat Papua. Pemerintah Indonesia mengafirmasi Papua tidak hanya di tataran elitis dengan memanggil elit-elit di Papua melainkan memulai program dari akar rumput. Hal ini kemudian membuka kemungkinan bagi penyelesaian konflik melalui pergeseran dari struktur hubungan yang sudah ada menuju struktur hubungan yang lain. Struktur kekuasaan yang tidak setara atau tidak stabil antara pemerintah Indonesia dengan orang Papua dipengaruhi oleh sejumlah penopang yang variatif. Karenanya dengan menghilangkan penyangganya dapat meruntuhkan struktur yang tidak stabil. Selain itu pihak ketiga dapat memperkuat dan memberdayakan pihak yang lemah sehingga pihak yang lemah (warga asli Papua) dapat menarik diri dari struktur yang tidak seimbang dan mampu membangun hubungan yang baru lewat institusi paralel. Penyangga yang dimaksud adalah hasil dari proses pada tahap pertama yakni gerakan para pendatang yang bergerak secara sosial dan kultural baik terhadap masyarakat Papua yang pro NKRI maupun yang "pro Bintang Kejora".

Kedua, yakni proses konfrontasi konflik dengan melihat hubungan apa yang hendak diubah. Pendatang dapat melakukan analisa lebih mendalam terhadap persoalan semacam ini. Hubungan tersebut bersifat kompleks yakni berhubungan dengan sejarah, kultur, dan ekonomi. Itu sebabnya hubungan antara pemerintah Indonesia dengan masyarakat Papua bersifat tidak simetris. Secara teoritis digambarkan bahwa para pendatang dapat melihat keseimbangan macam apakah yang dibutuhkan oleh masyarakat Papua. Apakah menghendaki semacam kekuasan baru di daerah. Pihak ketiga dapat membantu secara transpormatif jika berkonfrontasi dengan pihak yang lebih kuat yakni pemerintah Indonesia. Hal ini bermakna mengarahkan hubungan yang tidak damai dan tidak seimbang ke dalam hubungan yang penuh damai dan dinamis (ibid: 19).

Konflik tidak simetris merupakan dinamika konflik yang akarnya teletak pada masalah dan kepentingan antara pemerintah Indonesia dengan 
Papua yang dapat memisahkan struktur dan hubungan antar pihak-pihak yang terlibat. Karenanya struktur peran dan hubungan antara Indonesia dan Papua dapat dilakukan dengan mengalihkan energi negatif di atas. Karena itulah, perubahan struktural jangka panjang bukan melulu dapat diartikan dengan pembangunan dan perubahan ekonomi masyarakat untuk mempersiapkan jalan menuju kemajuan dan masyarakat yang adil. Proses pembangunan juga menghasilkan kestabilan masyarakat Papua sehingga tidak menghasilkan ketegangan di tataran masyarakat maupun di tataran elit Papua (I Ngurah Suryawan, 2010: 107).

Ketiga, yakni negosiasi dan mediasi untuk memperoleh kesepakatan bersama antar masyarakat dan seluruh perwakilan atau elit pihak-pihak yang berkonflik. Tahap ini menjadikan pihak ketiga sebagai mediator dalam proses dialog antara pemerintah Indonesia dengan masyarakat Papua. Peran pendatang dapat diposisikan sebagai pihak penting dalam upaya melakukan dialog antara Pemerintah Indonesia dengan masyarakat Papua. Mengingat selama ini, pendatang hanya mendapat informasi yang terbatas mengenai dialog antara Pemerintah Indonesia dan Papua (Rohaiza Ahmad Asi dkk, 2011: 45). Diperlukan pengertian yang lebih mengenai posisi pendatang dan pandangan serta keterlibatan pendatang dalam dialog. Keterlibatan para pendatang patut diprioritaskan dan diakomodasi. Perwakilan pendatang juga dituntut berpartisipasi menuangkan pandangannya mengenai konflik Papua yang selama ini belum terselesaikan

\section{E. Kesimpulan}

Masyarakat Papua secara umum dalam representasinya terbelah menjadi dua yakni masyarakat yang pro pemerintah Indonesia dan yang pro dengan kemerdekaan Papua. Konflik dengan pemerintah Indonesia kerap dipicu oleh sekelompok masyarakat yang pro terhadap kemerdekaan Papua. Masyarakat Papua yang masuk dalam kategori pro kemerdekaan memiliki tingkat simpati yang besar terhadap OPM yang hingga hari ini masih berjibaku dengan TNI.

Begitu halnya dengan pendatang. Pendatang dapat diklasifikasikan menjadi dua yakni pendatang inovatif dan pendatang konservatif. Pendatang pertama memiliki tujuan ke Papua untuk bekerja di sektor-sektor yang sesuai dengan keahliannya. Sedangkan pendatang kedua datang ke Papua setelah adanya kebijakan transmigrasi di era orde baru. Resistensi masyarakat Papua yang pro kemerdekaan ditujukan kepada pendatang yang inovatif karena dianggap mengancam secara ekonomi dan sosial. Lapangan kerja yang harusnya diisi oleh masyarakat lokal akhirnya diambil alih oleh pendatang dengan kompetensi kerja yang lebih baik. Kecemburuan sosial terjadi. Sedangkan pendatang konservatif relatif lebih diterima.

Dari hasil kajian analisa deskriptif melalui penelusuran literatur dan konstruksi teoritis tentang pembangunan perdamaian, peran pendatang dalam transformasi konflik Papua dapat dilakukan melalui 
tiga langkah strategis. Pertama, pendatang memberi sosialisasi secara kultural dengan prinsip penuh kehati-hatian, sehingga masyarakat Papua dapat mengorganisasikan diri mereka sendiri dan mengartikulasikan keluhan mereka secara positif. Kedua, konfrontasi dengan mensejajarkan diri dengan pemerintah Indonesia yang mempunyai kekuasaan lebih besar. Ketiga, negoisasi untuk bergabung merekonstruksi hubungan yang lebih adil dan lebih pantas untuk dapat mentransformasi konflik tanpa kekerasan.

\section{Daftar Pustaka}

Al Rahab, Amiruddin. 2010. Heboh Papua: Perang, Trauma, dan Separatisme. Jakarta: Komunitas Bambu.

Asi, Rohaiza Ahmad dkk. 2011. Pengelolaan Konflik di Indonesia-Sebuah Analisis Konflik di Maluku, Papua dan Poso. Jakarta: LIPI dan CHD.

Bertrand, Jaques. 2012. Nasionalisme dan Konflik Etnis di Indonesia (Terj.Ahmad). Yogyakarta: Penerbit Ombak, 2012.

G. Pruitt, Dean dan Rubin, Jeffrey Z. 2009. Teori Konflik Sosial. Yogyakarta: Pusataka Pelajar.

Miall, Hugh, Ramsbotham, Oliver, \& Woodhouse, Tom. 2002. Resolusi Damai Konflik Kontemporer (Terj, Tri Budhi Satrio). Jakarta: Rajawali Press.

Ngadisa. 2003. Konflik Pembangunan dan Gerakan Politik di Papua. Jakarta: Pustaka Raja.
Pamungkas, Cahyo. 2016. "Muslim Papua dan Muslim Pendatang Pertarungan Identitas Antara Keindonesiaan dan Kepapuaan.” Kawistara, Vol.6 (3): 225-324.

Pickering, Pec. 2001. How To Manage Conflict: Winwin Solution (Terj. Masri Maris). Jakarta: Penerbit Airlangga.

Rusli, Said. 1996. Pengantar Ilmu Kepundudukan Cetakan VII. Jakarta: LP3S.

Suryawan, I Ngurah. 2010. Genealogi Kekerasan dan Pergolakan Subaltern. Jakarta: Kencana.

Suryawan, I Ngurah, 2013. "Antropologi Gerakan Sosial: Membaca Transformasi Budaya di Kota Manokwari Papua Barat.” Jurnal Humaniora, Vol. 23 (3): 290-300

Sunarto. 1985. Penduduk Indonesia dalam Dinamika Migrasi 1971-1980. Yogyakarta: Dua Dimensi.

Susan, Novri. 2010. Pengantar Sosiologi Konflik dan Isu-isu Konflik Kontemporer. Jakarta: Kencana.

Tohari, Amien dkk. 2011. Dinamika Konflik dan Kekerasan di Indonesia. Jakarta: Tifa Foundation dan Institut Titian Perdamaian.

Wekke, Ismail Suardi. 2013. "Islam di Papua Barat: Tradisi dan Keberagaman." Ulul Albab: Jurnal Studi Islam, Vol. 14 (2): 117-134

\section{Sumber Online}


Jurnal Pemikiran Sosiologi Volume 7 No.2 2020

Kajian Awal tetang Peran Pendatang dalam Transformasi Konflik di Papua

Mohamad Baihaqi

(https://regional.kompas.com/read/2019/09/26/05

330041/7-fakta-baru-kerusuhan-wamena-

30-orang-tewas-hingga-dalang-

kerusuhan?page=all) . Diakses 7 Desember

2019, pukul 16.05 WIB

(https://regional.kompas.com/read/2019/10/01/06

360081/cerita-warga-pendatang-

diselamatkan-orang-asli-papua-saat-

kerusuhan-wamena?page=all.) Diakses 7

Desember 2019, pukul 16.05 WIB

(https://www.kompas.com/tren/read/2019/08/21/

172214665/4-pesan-jokowi-tanggapi-

kerusuhan-di-papua?page=all).

Diakses pada 04 Desember 2019, pukul 20.33 WITA

(https://www.papua.go.id/view-detail-berita-

6803/gubernur-pernyataan-presiden-tak-

obati-luka-rakyat-papua.html). Diakses pada

04 Desember 2019, pukul 20.33 WITA 